\title{
Vulnerability assessment of residential buildings to tidal flood hazards in Sriwulan Village, Sayung District, Demak Regency
}

\author{
Sani Afifah and Dyah Rahmawati Hizbaron* \\ Departement of Environmental Geography, Faculty of Geography, Universitas Gadjah Mada, Yogyakarta, Indonesia
}

\begin{abstract}
Tidal floods are among the destructive hazards to coastal settlements. In December of 2017, extreme tidal floods impacted 3,500 houses in Sriwulan Village, Sayung District, Demak Regency. This research was intended to (1) asses the vulnerability levels of the residential buildings and (2) analyze the most influencing factors. The assessment was based on the scenarios built with a $150 \mathrm{~cm}$-high tidal flood, as observed during the 2017 event and projected for the subsequent five years (2022). The Analytical Hierarchy Process (AHP) and Spatial Multi-Criteria Evaluation (SMCE) were used in four scenarios, namely, hazard, physical, environmental, and economic. The equal scenario was also developed as a comparison to the first four scenarios to achieve the second objective. Based on the physical, environmental, and equal scenarios, 22 houses distributed throughout most of the areas of Nyangkringan Sub-Village fell into the category of highly vulnerable. The most determinants of the vulnerability are related to the physical and environmental parameters. The former includes the design flood elevation, building maintenance, and building materials, while the latter consists of the source of tidal floods and their preventive measures, distance to water bodies, and accessibility.
\end{abstract}

\section{Introduction}

The Indonesian shore stretches as far as $81,000 \mathrm{~km}$, constituting up to $14 \%$ of the total shoreline worldwide [1]. With this condition, there are different threats to coastal areas, starting from erosion to floods, high waves, and even tsunamis. Tidal floods, locally known as rob, commonly take place in coastal lowlands, including Demak Regency that has been hit repeatedly by these disasters since the 1980s [2]. The high frequency of occurrences is attributable to a local factor, that is, land subsiding at $0.06-1.15 \mathrm{~m}$ per year [3]. Sayung is the most severely affected district in the regency. It has a relatively flat morphology with altitudes in the range of $0-5$ meters, which is partially responsible for the chronic flooding [4]

Sriwulan, a village of the district, receives the most adverse impact. In 2010, hundreds of houses in the village were inundated as deep as adult knee and up to one meter [5]. Towards the end of 2017, seawater tides flooded 3,500 houses up to $50-150 \mathrm{~cm}$ due to the impact of Tropical Cyclone Dahlia [6].

Apart from the year-to-year variation of tidal floods, inundation also varies in depth depending on the average height of the design flood elevation. Without raised foundations, houses are expected to be submerged permanently by the floods. Tidal floods cause physical damages to local residential buildings and economic losses due to inevitable retrofitting costs.

Both of these are believed to be the detrimental effects because, typically, these buildings can last for approximately 25 years without repair [7]. In this context, houses are one of the elements at risk, and the majority of settlements in coastal areas do not have longterm planning to deal with disasters; for this reason, their vulnerability must be analyzed [8].

Vulnerability analysis demands multifaceted development to incorporate various parameters and, consequently, accommodate types of factors that control the vulnerability level of a residential building. Therefore, from many methods of vulnerability, this research use Spatial Multi Criteria Evaluation (SMCE) due to its ability to accommodate vulnerabilities in various scenarios that use variables sourced from many types of data as the input [9]. Then, this research was designed to (1) assess the vulnerability level of residential buildings to tidal flood hazards in some scenarios and (2) identify the most influencing factors.

\section{Research Method}

This research took place in Sriwulan Village, Sayung District, Demak Regency with residential buildings as the unit of analysis. Due to the large size of the research population (i.e., all houses in the village that had experienced tidal floods), the sample size was determined by the Slovin method. The equation used was as follows.

$$
n=\frac{N}{1+\left(N e^{2}\right)}
$$

$$
\begin{aligned}
& \text { where: } \\
& n \quad=\text { Sample Size } \\
& N=\text { Population Size } \\
& e \quad=\text { Error Level }=5 \% \text { or equal to } 95 \% \text { accuracy }
\end{aligned}
$$

\footnotetext{
* Corresponding author: dyah.hizbaron@ugm.ac.id
} 
The tidal floods in 2017 inundated 3,500 houses in Sriwulan Village [6]. Therefore, based on the Slovin's equation, the sample size was 359 houses and added with 20 more houses to anticipate data biases. As a result, the total sample was 379 houses.

The research used systematic sampling to produce evenly distributed samples against the population by firstly dividing the study area into $30 \times 30 \mathrm{~m}^{2}$ grids. In addition, Sriwulan Village consists of six (6) subvillages, namely Nyangkringan, Sriwulan, Pututan, and Pondok Raden Patah Housing Phases 1, 2, and 3. The sampled houses in every sub-villages are presented in Figure 1.

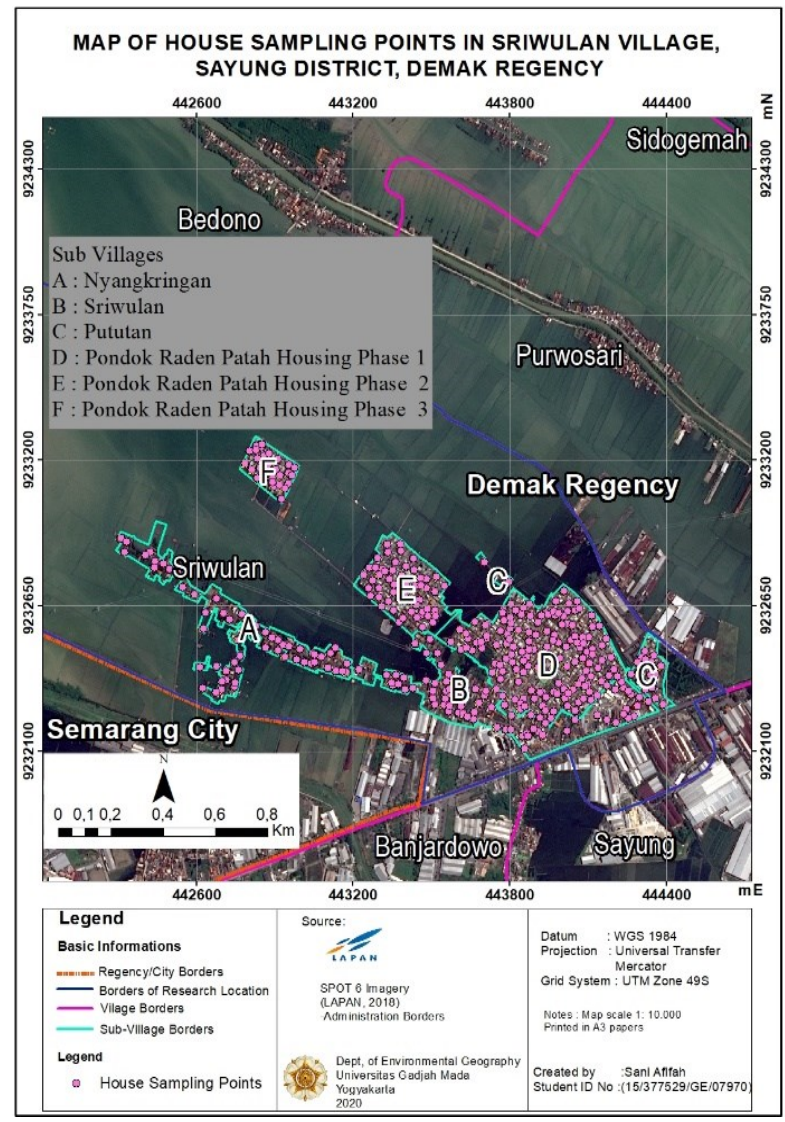

Fig. 1. The Distribution Map of House Sampling Points.

This research consists of four phases, known as preparing, collecting, processing, and analysing data. Preparing data included geospatial database, sample size, and literature review. The first one was collected from relevant agencies, while the others were carried out from desk research.

The parameters were determined based on the results of the data availability from literature study and preliminary survey of households (Table 1). Collecting data used two methods. At the beginning, structured interviews with questionnaire were conducted with the head or member of households who were able to describe variables or factors that constructed hazard, physical, and environmental parameters. On the next occasion, in-depth interview technique was obtained to explain economic parameter that represented losses as a result of tidal flood disaster. This technique was retrieved with key informant who was the head of development affairs in Sriwulan Village.
Table 1. Research Variables and Their References

\begin{tabular}{|c|c|c|}
\hline Variables & Definitions & Source \\
\hline \multicolumn{3}{|c|}{ Hazard } \\
\hline Depth & $\begin{array}{l}\text { Water depth inside the house } \\
\text { during the highest tidal flood } \\
\text { with reference to the ground } \\
\text { floor }\end{array}$ & {$[10]$} \\
\hline Frequency & $\begin{array}{l}\text { Recurrence flood with a } \\
\text { current size that will be the } \\
\text { same or exceeded in period of } \\
\text { the years. }\end{array}$ & {$[11]$} \\
\hline Duration & $\begin{array}{l}\text { Long-time of water to recede } \\
\text { from the house during the } \\
\text { highest tidal flood }\end{array}$ & $\begin{array}{l}{[10-} \\
11]\end{array}$ \\
\hline \multicolumn{3}{|c|}{ Physical Parameter } \\
\hline $\begin{array}{l}\text { Design Flood } \\
\text { Elevation }\end{array}$ & $\begin{array}{l}\text { Specific elevation constructed } \\
\text { by local community perception } \\
\text { to protect the house building } \\
\text { from peak of highest flood }\end{array}$ & $\begin{array}{l}{[11-} \\
12]\end{array}$ \\
\hline $\begin{array}{l}\text { Building } \\
\text { maintenance } \\
\text { or existing } \\
\text { damage }\end{array}$ & $\begin{array}{l}\text { Percentage of existing damage } \\
\text { presenting the building } \\
\text { maintenance }\end{array}$ & {$[13]$} \\
\hline $\begin{array}{c}\text { Type of } \\
\text { Materials }\end{array}$ & $\begin{array}{c}\text { Building construction based on } \\
\text { type of materials related to salt } \\
\text { weathering }\end{array}$ & {$[14]$} \\
\hline \multicolumn{3}{|c|}{ Environmental Parameter } \\
\hline $\begin{array}{l}\text { Source of } \\
\text { tidal flood } \\
\text { and their } \\
\text { preventive } \\
\text { measures }\end{array}$ & $\begin{array}{l}\text { The source of tidal flood and } \\
\text { the availability of a pump as a } \\
\text { preventive measure due to its } \\
\text { duration }\end{array}$ & {$[15]$} \\
\hline $\begin{array}{l}\text { Distance to } \\
\text { water bodies }\end{array}$ & $\begin{array}{l}\text { Distance of house building to } \\
\text { water bodies (pond/river } \\
\text { connected to the sea) related to } \\
\text { the potential damage from salt } \\
\text { weathering }\end{array}$ & {$[16]$} \\
\hline Accessibility & $\begin{array}{l}\text { Availability of a way or bride } \\
\text { during the flood }\end{array}$ & {$[17]$} \\
\hline \multicolumn{3}{|c|}{ Economic Parameter } \\
\hline $\begin{array}{l}\text { Retrofitting } \\
\text { cost }\end{array}$ & $\begin{array}{l}\text { Cost needed to make changes } \\
\text { within } 7 \text { years (2013-2019) for } \\
\text { an existing building in order to } \\
\text { protect it from flooding }\end{array}$ & {$[12]$} \\
\hline $\begin{array}{l}\text { Building } \\
\text { type }\end{array}$ & $\begin{array}{c}\text { Type of building representing } \\
\text { investment cost }\end{array}$ & {$[7,18]$} \\
\hline Building area & $\begin{array}{l}\text { Total area of building related } \\
\text { to the cost for elevating base } \\
\text { floor }\end{array}$ & {$[19]$} \\
\hline
\end{tabular}

The vulnerability data were processed in two steps, namely variables weighting by Analytical Hierarchy Process as well as vulnerability level mapping using several scenarios set in the Spatial Multi-Criteria Evaluation. 
Last of all was data analysis. This phase used interpolation to understand the spatial patterns in some scenario. Subsequently, these spatial patterns were compared to identify the most determining factor(s) of the vulnerability.

\subsection{Analytical Hierarchy Process (AHP)}

This research used Analytical Hierarchy Process (AHP) to obtain weight values of variables within parameters (physical, environmental, hazard, and economic) to create vulnerability map. AHP was chosen because it was able to accommodate analytical object, both quantitative and qualitative information into mathematical models [20]. Decomposition as the onset would be considered to separate that information by problem into hierarchy based on the results of field survey and literature studies [21].

AHP step were subsequently decision comparison, which was based on how one parameter took priority over the other parameters at the same level [22]. It was known as pairwise comparison that consisted of nine points (Table 2).

Table 2. Scales of Priority in the Analytic Hierarchy

\begin{tabular}{|c|c|c|c|c|c|}
\hline \multicolumn{6}{|c|}{ Process (AHP) } \\
\hline \multirow{5}{*}{ 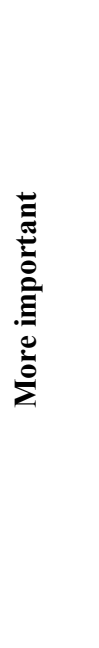 } & $\begin{array}{c}\text { Equally } \\
\text { important }\end{array}$ & 1 & \multirow{5}{*}{ 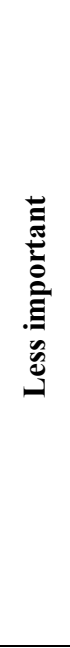 } & $\begin{array}{l}\text { Equally } \\
\text { important }\end{array}$ & 1 \\
\hline & $\begin{array}{c}\text { Slightly } \\
\text { more } \\
\text { important }\end{array}$ & 3 & & $\begin{array}{l}\text { Slightly more } \\
\text { important }\end{array}$ & $1 / 3$ \\
\hline & $\begin{array}{c}\text { More } \\
\text { important }\end{array}$ & 5 & & Less important & $1 / 5$ \\
\hline & $\begin{array}{l}\text { Extremely } \\
\text { important }\end{array}$ & 7 & & $\begin{array}{l}\text { Slightly less } \\
\text { important }\end{array}$ & $1 / 7$ \\
\hline & $\begin{array}{l}\text { Absolutely } \\
\text { important }\end{array}$ & 9 & & $\begin{array}{c}\text { Absolutely less } \\
\text { important }\end{array}$ & $1 / 9$ \\
\hline $2,4,6,8$ & \multicolumn{5}{|c|}{$\begin{array}{c}\text { Values between the two considered adjacent } \\
\text { values }\end{array}$} \\
\hline
\end{tabular}

This step produced eigenvectors with their rank which is representing relative importance of variables in each parameter, as presented in Table 3. Eigenvector bellow has been throughout consistent evaluation which is marked with consistency ratio $(\mathrm{CR})$ value at $<10 \%$, as shown in figure 2. $\mathrm{CR}$ is resulted by dividing consistency index (CI) with random index (r.i). ri value relies on the number of criteria (n) according to Saaty (1980) [22]. In this case, an add-in program for Microsoft Excel, namely, the AHP calculator, was used. This program would generate CR value automatically after adding the number of criteria(s) and their name.
Table 3. The Weighting Results of the Research Parameters

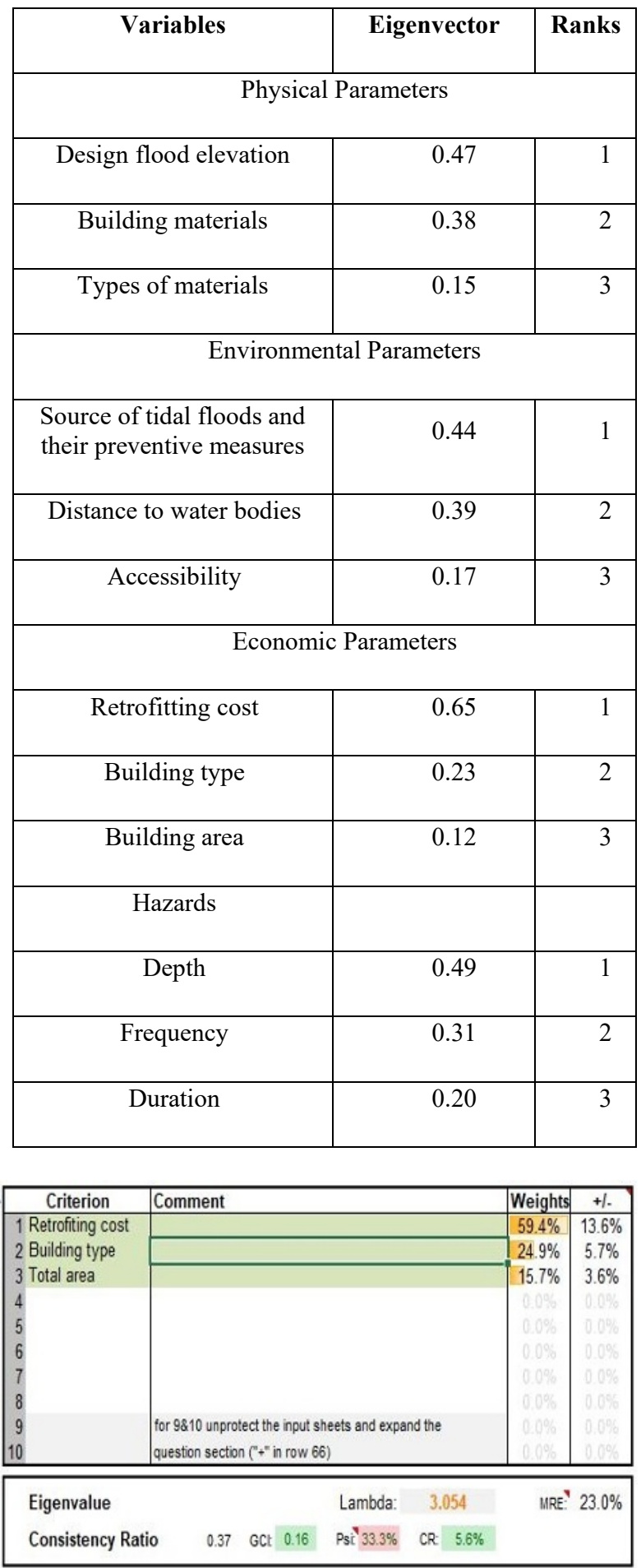

Fig. 2. Consistency Ratio $<10 \%$

Furthermore, AHP calculator had an ability to give recommended scale for relative weighting to create better consistency (Figure 3), considered as an illustration of inconsistent pair-wise comparisons. The darkest red highlight which is showing the relative importance between retrofitting cost (A) and total area (B), is the most inconsistent judgement, therefore, AHP Calculator recommend 1 for A criteria rather 3 scale for better consistency ratio. 


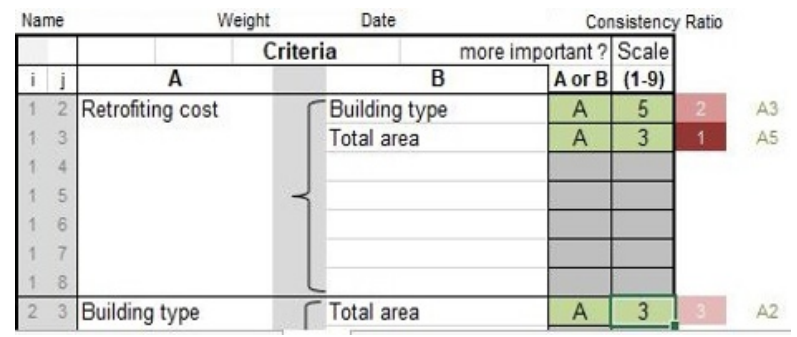

Fig. 3. Scale Recommendation from AHP Calculator

\subsection{Spatial Multi-Criteria Evaluation (SMCE)}

SMCE can explain future uncertainties with mathematical logics using criteria tree analysis, standardization, weighting, and generate scenarios [23]. The criteria tree consists of maps of the research variables or criteria (Figure 4).

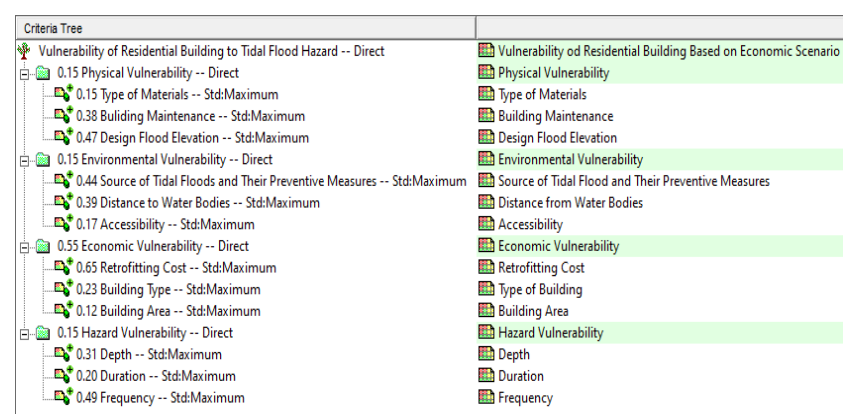

Fig. 4. The Criteria Tree.

Standardization is a process in which all different unit indicators are equated with the corresponding data standards or normalization. SMCE can standardize the inputted data that have various categories or classifications. The study used the standardization of benefits $(+)$, which indicate that all of the variables have greater contribution to the vulnerability [23]. The method used was fuzzy logic, which produced values in the range of 0 to 1 [24]. The higher the score of category, the higher the vulnerability (Table 5).

Afterward, the weighting was carried out by the direct method, i.e., a technique used to input the quantitative data obtained from the previous AHP calculation. Generating scenarios played an important role in producing vulnerabilities in various by first deciding the dominant parameter and then assigning equal values to the other parameters, known as weighting scenario [23].

There were four scenarios: physical, environmental, economic, and hazard. The economic scenarios emphasized the contribution of economic parameters to vulnerability. The same case applied to the environmental, physical, and hazard scenarios, which relied on to what extent the corresponding parameters controlled the vulnerability. In each of these scenarios, the dominant parameters were given the highest weight value, while the remaining parameters were assigned the same weight. An equal scenario was also carried out to determine the level of vulnerability with the assumption that all parameters observed had an equal weight value (Table 4).
Table 4. The Weighting Results of the Research Parameters

\begin{tabular}{|c|c|c|c|c|}
\hline \multirow{2}{*}{ Scenarios } & \multicolumn{4}{|c|}{ Percentage of Weighting (\%) } \\
\cline { 2 - 5 } & Hazards & Physical & $\begin{array}{c}\text { Environ } \\
\text { mental }\end{array}$ & Economic \\
\hline Hazards & 55 & 15 & 15 & 15 \\
\hline Physical & 15 & 55 & 15 & 15 \\
\hline Environmental & 15 & 15 & 55 & 15 \\
\hline Economic & 15 & 15 & 15 & 55 \\
\hline Equal & 25 & 25 & 25 & 25 \\
\hline
\end{tabular}

Because the SMCE produced data with a normal distribution, the classification was conducted by the equal method [25]. In this case, each scenario has the same class size, which consist of three classes, i.e., low, moderate, and high classes.

\subsection{Interpolation}

The data were interpolated to distinguish the spatial patterns of vulnerability in each scenario using geostatistical wizard tool in Arc-GIS 10.3. This technique used the Radial Basis Function (RBF) due to its ability to produce spatial patterns that are more detailed than other methods from a large size of data point [26] (Figure 5a). Furthermore, it produces smaller root mean square error (RMSE) values than Inverse Distance Weighting (IDW) that produces the same characteristics (Table 6). The smaller of RMSE, the better performance of the spatial pattern model [27].

Table 6. The RMSE Value of Some Methods

\begin{tabular}{|c|c|}
\hline Interpolation Methods & RMSE Value \\
\hline Kriging & 0,462 \\
\hline Local Polynomial & 0,463 \\
\hline Radial Basis Functions & 0,491 \\
\hline Inverse Distance Weighting (IDW) & 0,497 \\
\hline
\end{tabular}

\subsection{Determination of the most influencing factors}

Future risks can be minimized by understanding factors that have the most significant role in shaping the vulnerability of a residential building to tidal floods. In this study, the most influencing factor(s) was determined by compiling as many scenarios as possible to be able to recognize the factor(s) that frequently appeared on the maps produced. Besides, it also used equal scenario in order to emphasize the finding [28]. The research stages are presented in details in the flow chart below (Figure 6). 
Table 5. Standardizations Definitions, and Source of Criteria Used in the Research

\begin{tabular}{|c|c|c|c|}
\hline Variables & Standardization Definitions & Category & References \\
\hline \multicolumn{4}{|c|}{ Hazard } \\
\hline Depth & $\begin{array}{l}(+) \text { The deeper the tidal } \\
\text { flood, the higher the } \\
\text { vulnerability }\end{array}$ & $\begin{array}{c}\text { Very low }(0.2)=\text { no flood }(0 \mathrm{~cm}) \\
\text { Low }(0.4)=\text { Ankle to leg }(1-49 \mathrm{~cm}) \\
\text { Moderate }(0.6)=\text { Knee to stomach }(50-100 \mathrm{~cm}) \\
\text { High }(0.8)=\text { Chest to check }(101-150 \mathrm{~cm}) \\
\text { Very High }(1.0)=\text { Above cheek }(>150 \mathrm{~cm})\end{array}$ & $\begin{array}{l}{[7,24, \text { and }} \\
\text { Field } \\
\text { survey }]\end{array}$ \\
\hline Frequency & $\begin{array}{l}(+) \text { The higher the frequency } \\
\text { of tidal flood, the higher the } \\
\text { vulnerability }\end{array}$ & $\begin{array}{c}\text { Low }(0.3)=\text { Never flooded within } 5 \text { years } \\
\text { Moderate }(0.6)=\text { flooded, maximum } 5 \text { times } \\
\text { within } 5 \text { years } \\
\begin{aligned} \text { High }(1.0)= & \text { Flooded, more than } 5 \text { times } \\
& \text { within } 5 \text { years }\end{aligned}\end{array}$ & $\begin{array}{l}{[12, \text { and }} \\
\text { field } \\
\text { survey }]\end{array}$ \\
\hline Duration & $\begin{array}{l}(+) \text { The longer the duration } \\
\text { of tidal flood, the higher the } \\
\text { vulnerability }\end{array}$ & $\begin{array}{c}\text { Very low }(0.2)=\text { No flood } \\
\text { Low }(0.4)=0.5 \text { hour }-12 \text { hours } \\
\text { Moderate }(0.6)=13 \text { hours }-24 \text { hours } \\
\text { High }(0.8)=25 \text { hours }-48 \text { hours } \\
\text { Very high }(1.0)=>48 \text { hours } \\
\end{array}$ & $\begin{array}{c}{[10,15,} \\
\text { and field } \\
\text { survey }]\end{array}$ \\
\hline \multicolumn{4}{|c|}{ Physical Parameter } \\
\hline $\begin{array}{l}\text { Design Flood } \\
\text { Elevation }\end{array}$ & $\begin{array}{l}(+) \text { The lower the design } \\
\text { flood elevation toward spring } \\
\text { tide, the higher the } \\
\text { vulnerability }\end{array}$ & $\begin{array}{c}\text { Low }(0.3)=\text { Above storm tide } 2017 \\
\text { Moderate }(0.6)=\text { Below storm tide } 2017 \\
\text { High }(1.0)=\text { Below spring tide }\end{array}$ & $\begin{array}{c}\text { [7 and field } \\
\text { survey] }\end{array}$ \\
\hline $\begin{array}{c}\text { Building } \\
\text { maintenance or } \\
\text { existing damage }\end{array}$ & $\begin{array}{l}(+) \text { The bigger the percentage } \\
\text { of building damage, the } \\
\text { higher the vulnerability }\end{array}$ & $\begin{array}{l}\text { Low }(0.3)=0-25 \% \text { existing damage } \\
\text { Moderate }(0.6)=50 \% \text { existing damage } \\
\text { High }(1.0)=100 \% \text { existing damage }\end{array}$ & $\begin{array}{l}\text { [13 and } \\
\text { field } \\
\text { survey] }\end{array}$ \\
\hline Type of Material & $\begin{array}{l}(+) \text { Wood is more vulnerable } \\
\text { than brick }\end{array}$ & $\begin{array}{c}\text { Low }(0.3)=\text { brick } \\
\text { Moderate }(0.6)=\text { brick }+ \text { wood } \\
\text { High }(1.0)=\text { Wood } \\
\end{array}$ & {$[14,19]$} \\
\hline \multicolumn{4}{|c|}{ Environmental Parameter } \\
\hline $\begin{array}{l}\text { Source of tidal } \\
\text { floods and their } \\
\text { measures }\end{array}$ & $\begin{array}{l}\text { (+) Source of tidal flood that } \\
\text { impacts on longer duration } \\
\text { will cause the higher } \\
\text { vulnerability }\end{array}$ & $\begin{array}{c}\text { Low }(0.3)=\text { Pump } \\
\text { Moderate }(0.6)=\text { pond/river/drainage } \\
\text { High }(1.0)=\text { bad drainage }\end{array}$ & $\begin{array}{l}{[15 \text { and }} \\
\text { field } \\
\text { survey }]\end{array}$ \\
\hline $\begin{array}{c}\text { Distance to water } \\
\text { bodies }\end{array}$ & $\begin{array}{l}(+) \text { The closer the distance of } \\
\text { building to water bodies, the } \\
\text { higher the vulnerability }\end{array}$ & $\begin{array}{c}\text { Low }(0.3)=>100 \text { meter } \\
\text { Moderate }(0.6)=50-100 \text { meter } \\
\text { High }(1.0)=0-50 \text { meter }\end{array}$ & $\begin{array}{l}\text { [16 and } \\
\text { field } \\
\text { survey] }\end{array}$ \\
\hline Accessibility & $\begin{array}{l}(+) \text { The lower the } \\
\text { accessibility, the higher the } \\
\text { vulnerability }\end{array}$ & $\begin{array}{c}\text { Low }(0.3)=\text { No inundation } \\
\text { Moderate }(0.6)=\text { There is inundation, but there is a way too } \\
\text { High }(1.0)=\text { There is inundation }\end{array}$ & $\begin{array}{l}{[17 \text { and }} \\
\text { field } \\
\text { survey }]\end{array}$ \\
\hline \multicolumn{4}{|c|}{ Economic Parameter } \\
\hline Retrofitting cost & $\begin{array}{l}(+) \text { The higher the retrofitting } \\
\text { cost, the higher the } \\
\text { vulnerability }\end{array}$ & $\begin{array}{c}\text { Very low }(0.2)=0 \\
\text { Low }(0.4)=\text { IDR }<9.000 .000 \\
\text { Moderate }(0.6)=\text { IDR } 10.000 .000-\text { IDR } 59.000 .000 \\
\text { High }(0.8)=\text { IDR } 60.000 .000-\text { IDR } 100.000 .000 \\
\text { Very high }(1.0)=\text { IDR }>100.000 .000\end{array}$ & $\begin{array}{l}\text { [10 and in- } \\
\text { depth } \\
\text { interview) }\end{array}$ \\
\hline Building type & $\begin{array}{l}(+) \text { The higher the } \\
\text { investment cost, the higher } \\
\text { the vulnerability }\end{array}$ & $\begin{array}{c}\text { Low }(0.3)=\text { non-permanent } \\
\text { Moderate }(0.6)=\text { semi-permanent } \\
\text { High }(1.0)=\text { permanent } \\
\end{array}$ & {$[7,18]$} \\
\hline Building area & $\begin{array}{l}(+) \text { The wider the area of } \\
\text { building, the higher the } \\
\text { vulnerability }\end{array}$ & $\begin{array}{c}\text { Very low }(0.2)=\left(36-49 \mathrm{~m}^{2}\right) \\
\text { Low }(0.4)=\left(50-69 \mathrm{~m}^{2}\right) \\
\text { Moderate }(0.6)=\left(70-119 \mathrm{~m}^{2}\right) \\
\text { High }(0.8)=\left(120-200 \mathrm{~m}^{2}\right) \\
\text { Very high }(1.0)=\left(201-360 \mathrm{~m}^{2}\right)\end{array}$ & $\begin{array}{l}19 \text { and } \\
\text { field } \\
\text { survey] }\end{array}$ \\
\hline
\end{tabular}



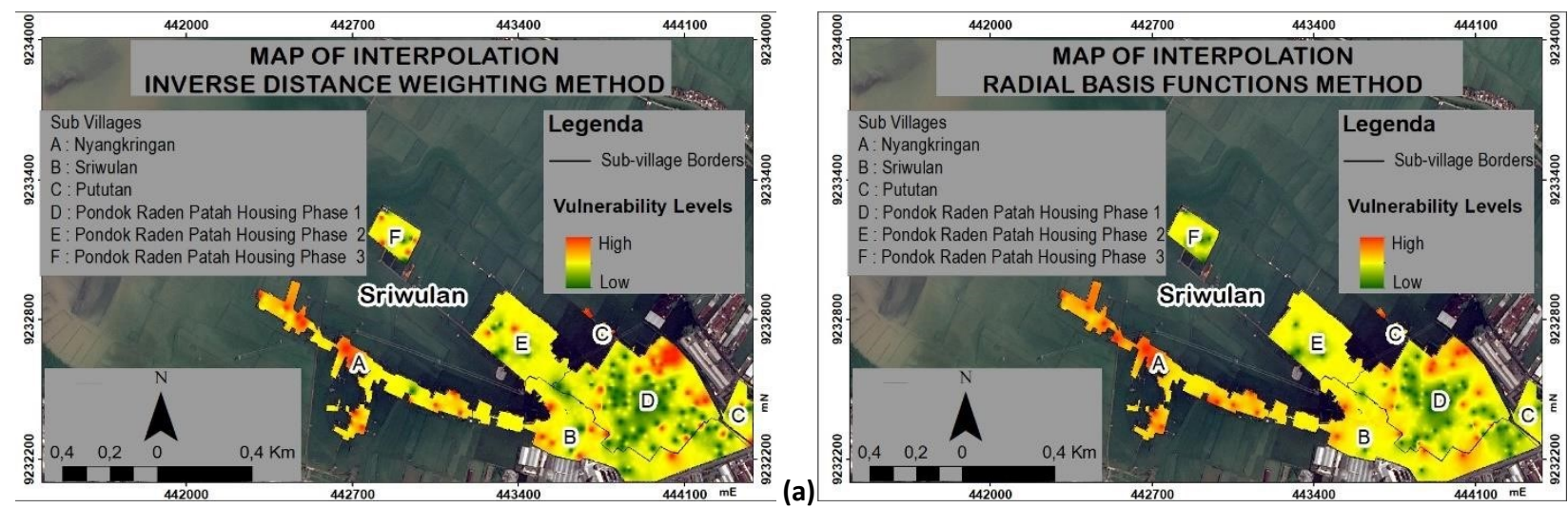

(b)
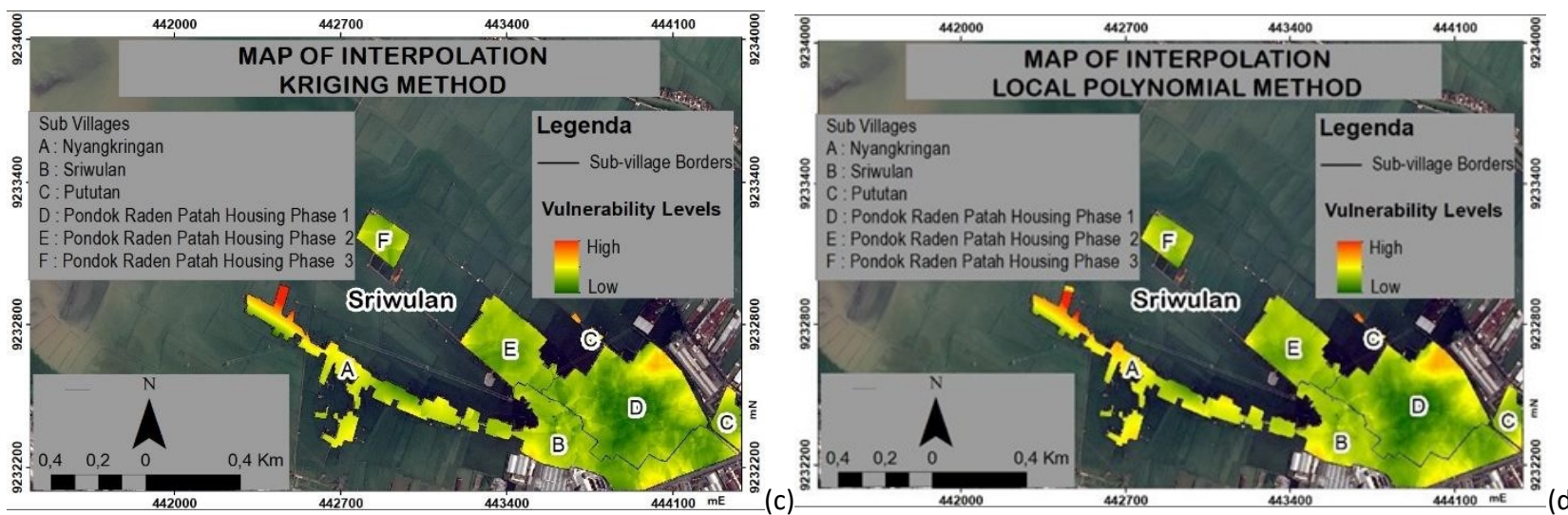

Fig. 5. Interpolation Map of Some Methods.

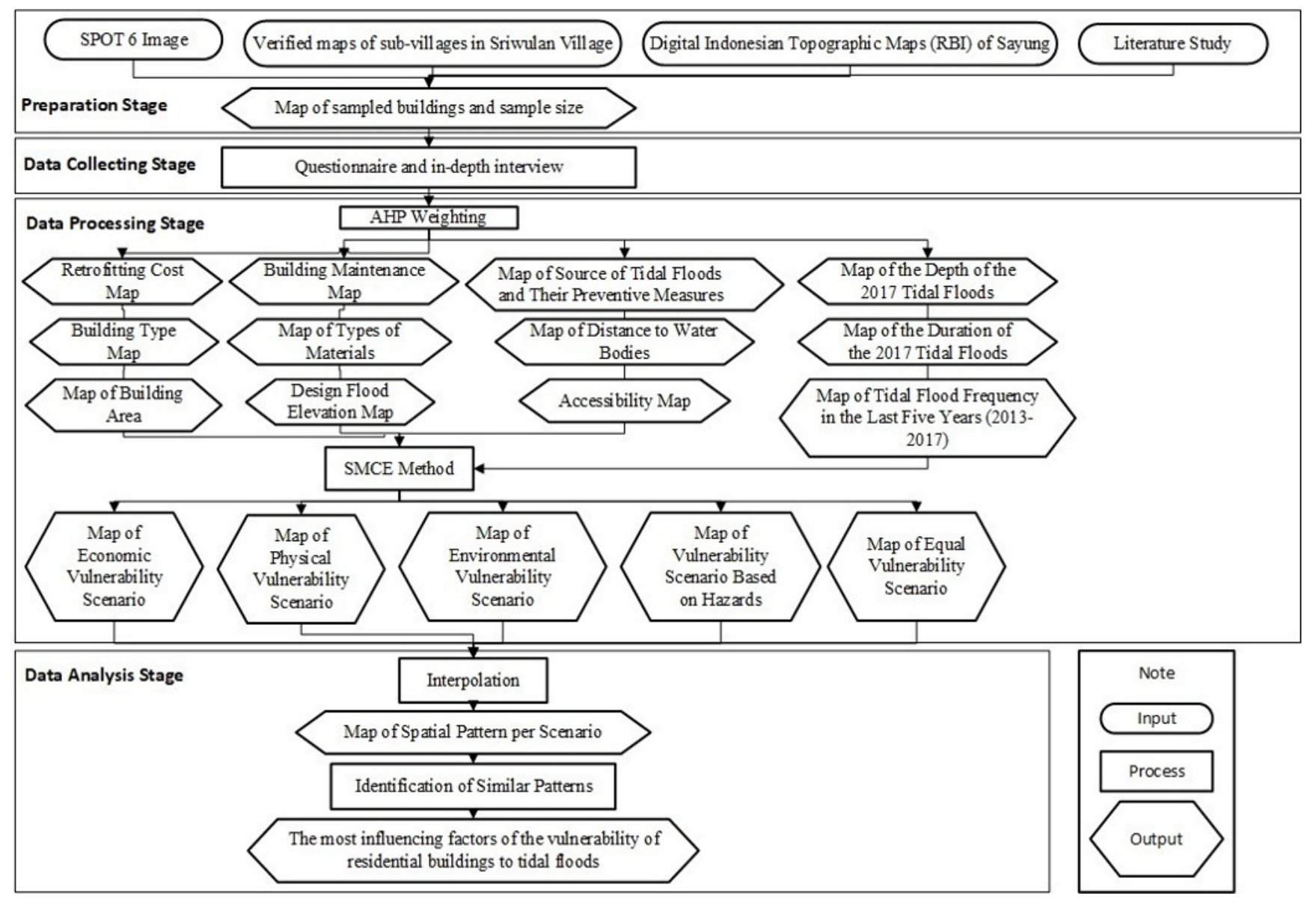

Fig. 6. Research Flow Chart 


\section{Result and Discussion}

\subsection{Hazard-Based Vulnerability Scenario}

The high tides on the Coast of Demak estimated would reach 145.42 to $163.50 \mathrm{~cm}$ in 2020-2025 [3]. In December of 2017 , storm tide as the combination of spring tide and storm surge hit the coast of Demak due to Tropical Cyclone Dahlia. With these references, the hazard scenario was generated to mimic the depth, duration, and frequency of the 2017 tidal floods with a height of $150 \mathrm{~cm}$.

The vulnerability mapping made with this scenario showed heterogeneous levels of vulnerability among the houses observed. Nevertheless, a dominant pattern of moderate vulnerability was apparent (Figure 7). Fiftythree houses or $14 \%$ of the total samples fell into the category of low vulnerability because they were not flooded during a storm tide that led to $150 \mathrm{~cm}$-deep inundation. In other words, a similar tidal flood in the future will not directly affect these houses [3]. Meanwhile, the other 291 houses (77\%) were classified as moderately vulnerable, and the remaining 35 houses (9\%) were highly vulnerable.

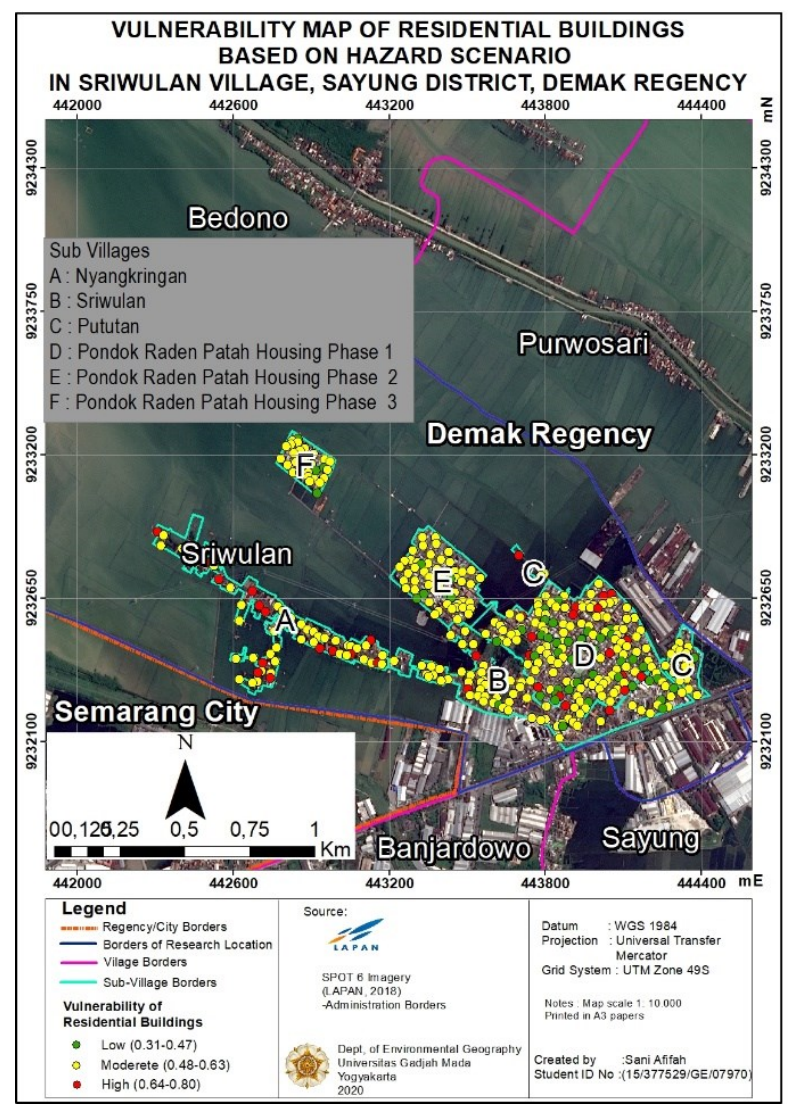

Fig. 7. Vulnerability Maps of Residential Buildings Based on Hazard Scenario.

Buildings with high vulnerability were identified mostly in Nyangkringan Sub-village. Few of them in Pondok Raden Patah Housing Phase 1, as well as one house in Pututan Sub-village. These houses are chest- to cheek-deep in water.

Besides, the frequency of inundation was more than five times within 5 years in some houses. The houses were flooded every day because the type of tidal waters of Demak Regency was mixed tide prevailing diurnal tide [4]. It was characterized by one tide and one ebb tide in a day, but sometimes for a while there were two tides and two ebb tides with the distinction of height and period [29]. Therefore, these houses were flooded at least once a day during daily tides (Figure 8)

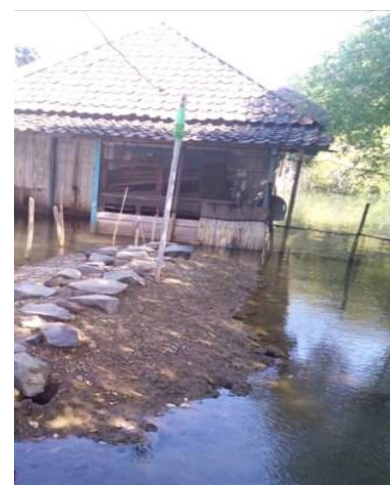

Fig. 8. House which was flooded at least once a day

On the other hands, there were some houses that inundated more than 48 hours in Pondok Raden Patah Housing Phase 1. Seawater flowing into these houses take a relatively long time to recede because it is retained in a long discharge channel before disposed to the sea. In addition, a few drainages in some houses became waste disposal sites, so it did not dry out before other drainages dried.

\subsection{Physical-Based Vulnerability Scenario}

Vulnerability scenarios that considered the current condition of design flood elevation, building maintenance, and types of materials revealed that more than half of the residential buildings were moderately vulnerable (226 houses or $60 \%$ of the total samples) and that the rest showed a heterogeneous pattern (Figure 9). Around 25 houses were highly vulnerable, while the remaining 128 houses (34\%) had a low vulnerability.

Most of these houses with low vulnerabilities were located in the centre of Pondok Raden Patah Housing Phase 1, mainly due to the design of flood elevation with a hight at least 2 meters.

In some parts of Nyangkringan Sub-village, the high physical vulnerability was dominant, but only a few shares of the houses in Sriwulan and Pututan Subvillages and Pondok Raden Patah Housing Phases 1, 2, and 3 were highly vulnerable to tidal floods. The residential buildings in these areas were mostly low to moderately vulnerable. The spatial pattern of physical vulnerability tends to change following modifications in its determinants.

\subsection{Environmental-Based Vulnerability Scenario}

The combination of distance to water bodies, source of tidal floods and their preventive measures, and accessibility generated an environmental vulnerability scenario, therefore, varying degrees of vulnerability 
with moderate levels dominating the houses (284 buildings or $75 \%$ of the total samples) (Figure 10). Seventy-one houses (19\%) fell into the category of low vulnerability, while only 24 houses $(6 \%)$ were highly vulnerable.

High vulnerabilities were found in the northern part of Pondok Raden Patah Housing Phase 1, mainly due to some drainage canals in this area are in poor condition. The floods originating from poor drainage systems will last longer than floods originating from the sea [15]. Another factor that caused the vulnerability was the distance to water bodies. The wooden walls decayed easily and the brick walls were prone during the calcification due to the highest saline content in buildings that was close to the water bodies [16]. Most of them were found in Nyangkringan Sub-village, as shown in figure 11.

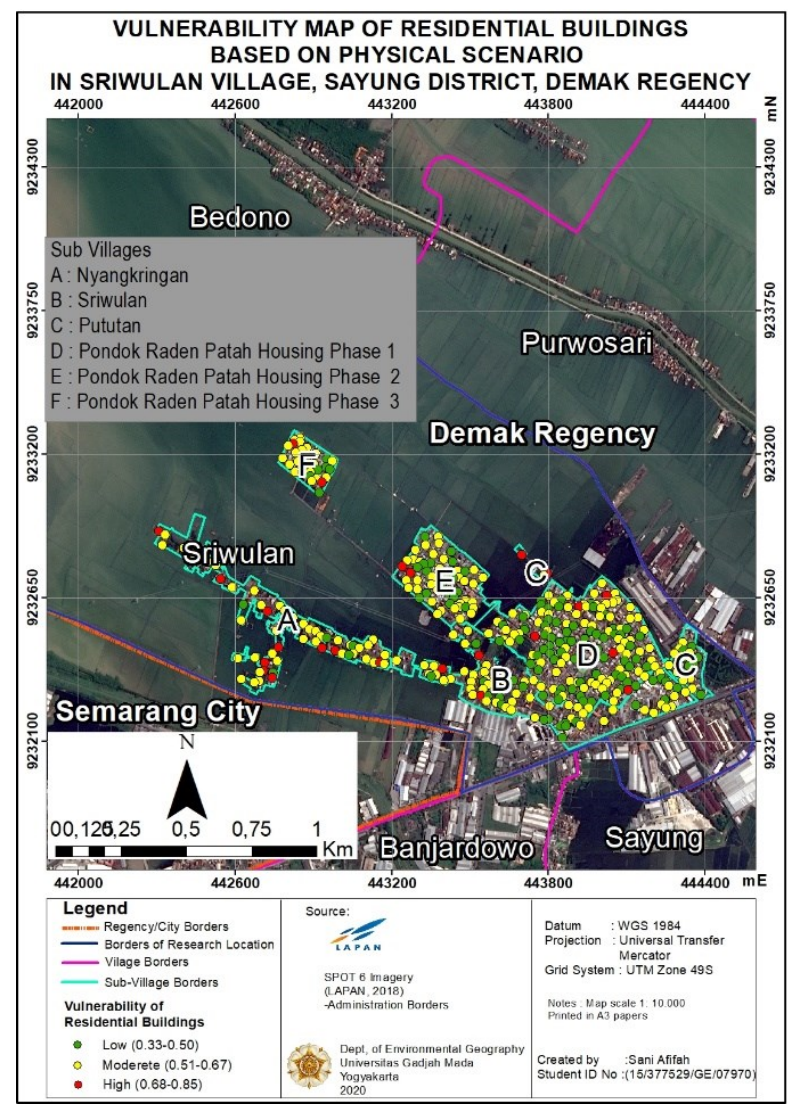

Fig. 9. Vulnerability Maps of Residential Buildings Based on Physical Scenario.

\subsection{Economic-Based Vulnerability Scenario}

The economic vulnerability scenario represents the economic losses due to tidal flood. This vulnerability took into account the current retrofitting costs, building type, and building area. The results also showed that, economically, three-quarters of the total samples (284 houses) were moderately vulnerable, while the rest samples had varying levels of vulnerability (Figure 12). Seventy-one houses $(19 \%)$ were categorized with low vulnerability, and another 24 houses $(6 \%)$ were highly vulnerable.

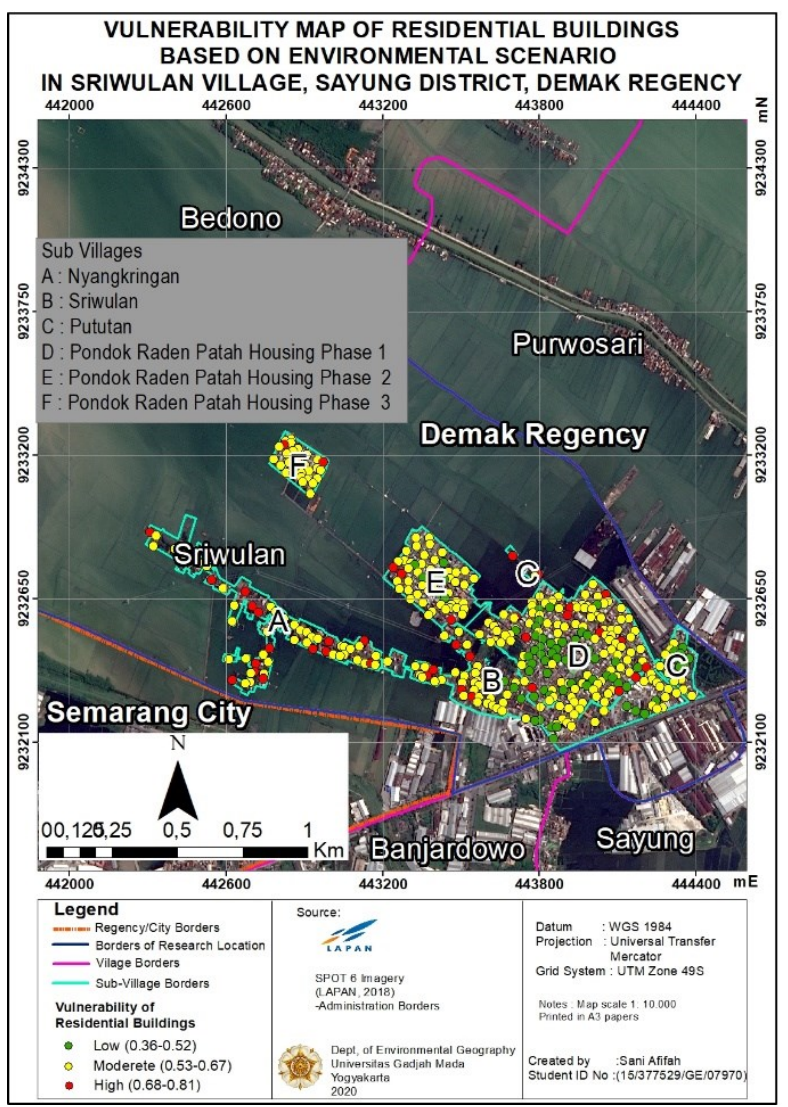

Fig. 10. Vulnerability Maps of Residential Buildings Based on Environmental Scenario

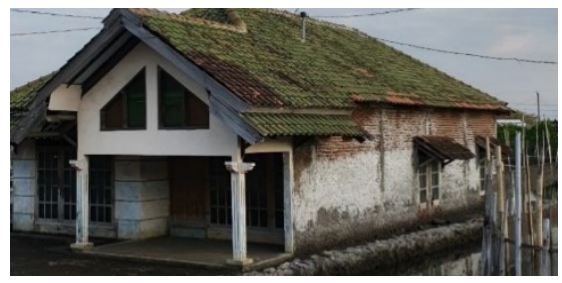

Fig. 11. House with high saline content in the wall

The economic vulnerability scenarios showed a slight spatial variation in high vulnerability in the east of Pondok Raden Patah Housing Phase 1, mainly due to the high retrofitting costs of several houses in this region. The highest cost of retrofitting method was when a homeowner rebuilt a new house from existing house, which was known as demolish (Figure 13) [12]. According to local people perception, this method usually needed at least IDR 60.000 .000 .

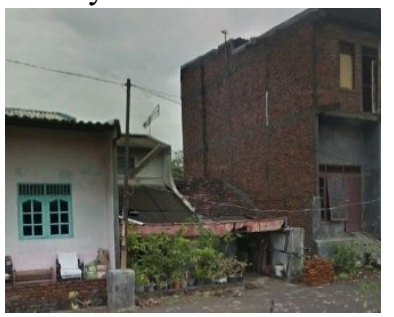

Before retrofitting : 2016

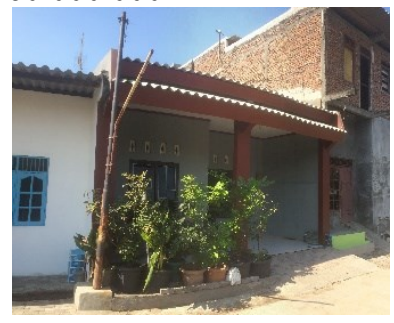

After retrofitting : 2019
Fig. 13. House with Demolish Retrofitting Method 


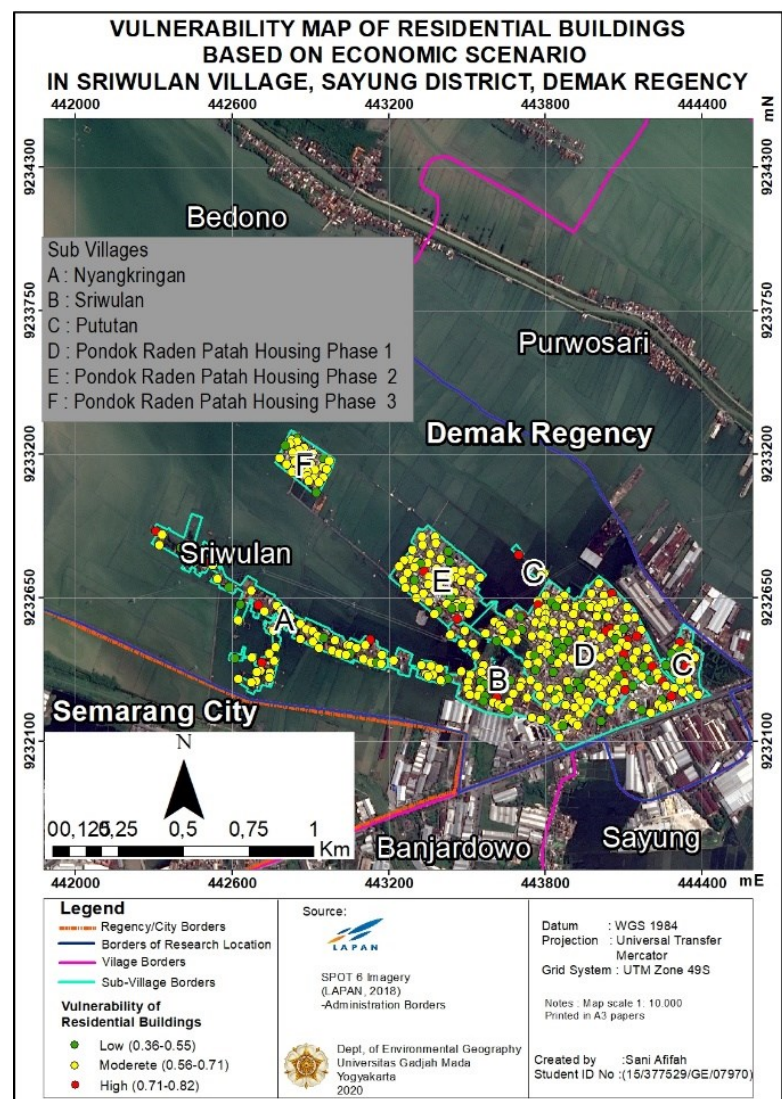

Fig. 12. Vulnerability Maps of Residential Buildings Based on Economic Scenario.

Another factor that caused vulnerability of house building toward tidal flood was building area. Based on in-depth interview, the cost that required to elevate ground floor with one-meter hight for $72 \mathrm{~m}^{2}$ was 10 dump truck of material, which was equal to IDR 8.000 .000 . The dominance of the buildings with $72 \mathrm{~m}^{2}$ was in Pondok Raden Patah Housing Phase 1, 2, and 3 because most of the buildings in this area had type 21 .

\subsection{The Most Determinants of Vulnerability}

An essential finding of this study is the specific spatial pattern produced in each scenario (Figures 14a-e). The scenarios revealed specific patterns that shared similarities, and when observed thoroughly, some factors emerged more frequently than the others. For instance, the physical and environmental scenarios had nearly identical spatial patterns, meaning that both scenarios have a robust pattern [23].

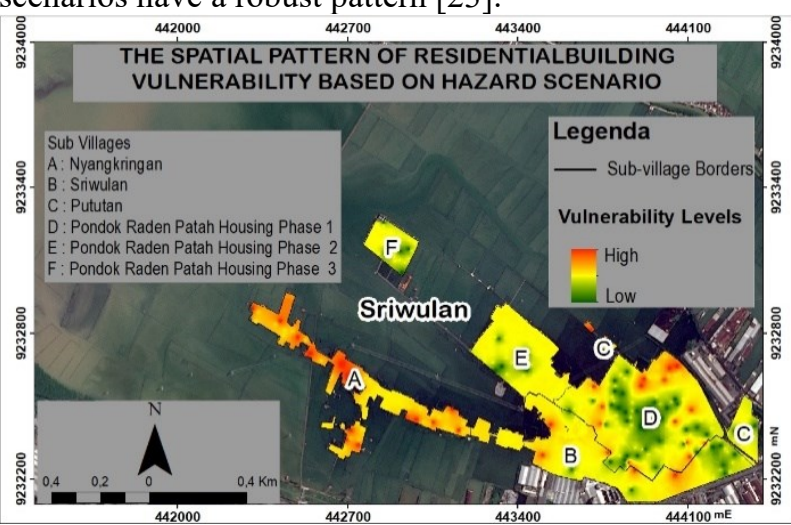

(a)

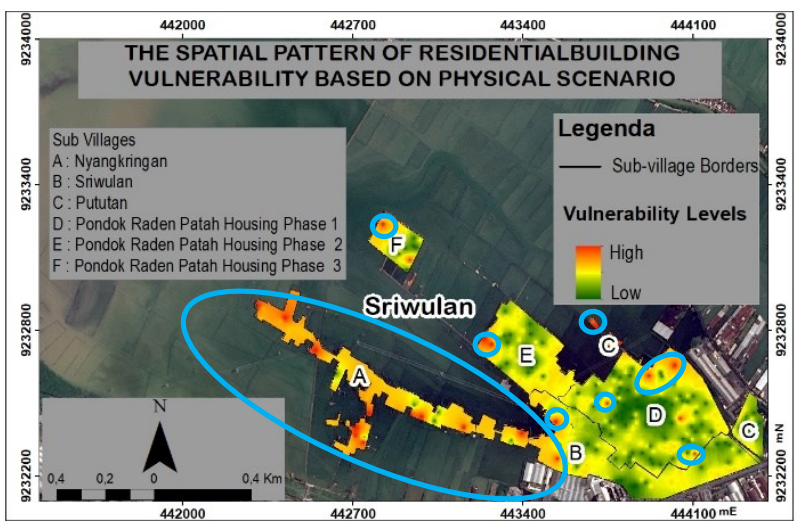

(b)
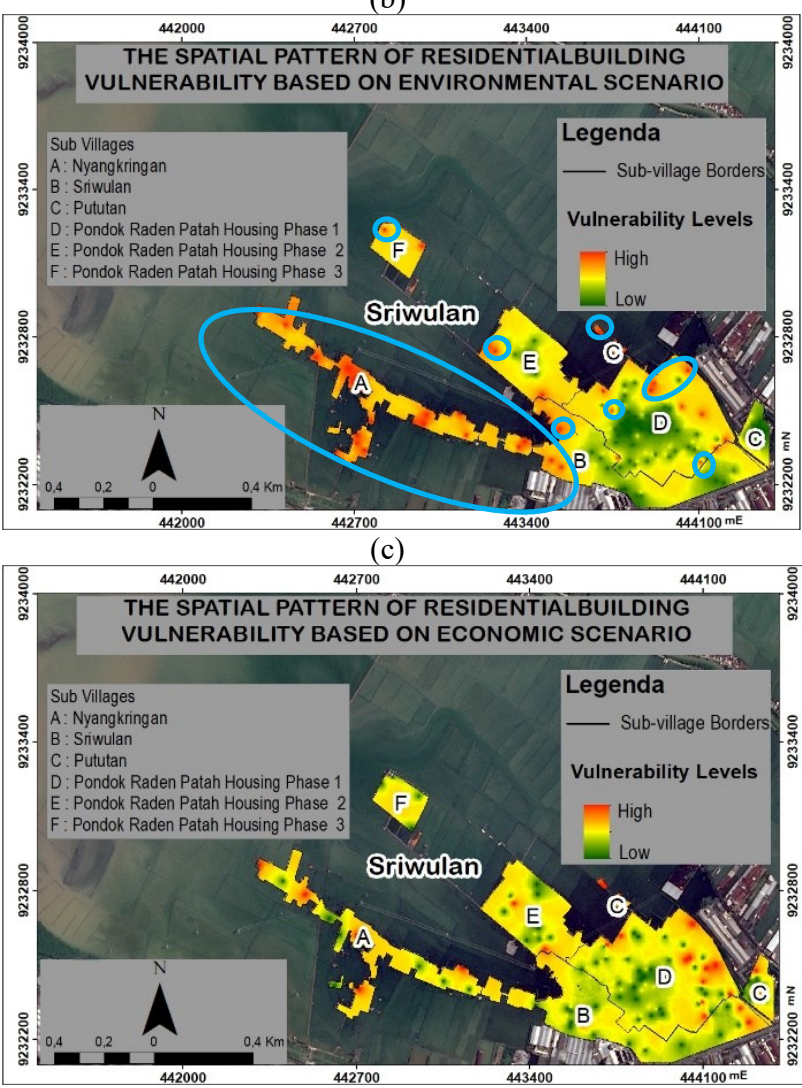

(d)

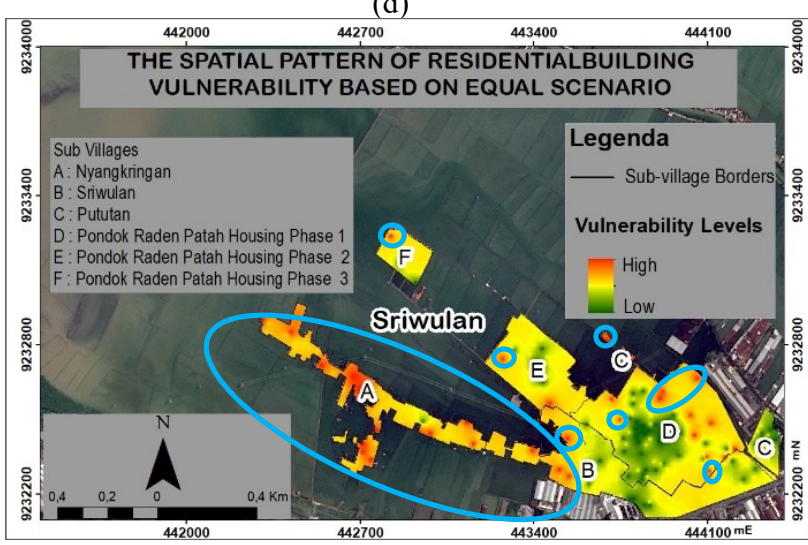

(e)

Fig. 14. The Spatial Patterns of Vulnerability in (a) Hazard, (b) Physical, (c) Environmental, (d) Economic, (e) Equal Scenarios.

The striking characteristics are the high vulnerability in most areas of Nyangkringan Sub-village. Also, a small proportion of high vulnerability was found in Pondok Raden Patah Housing Phase 1, Sriwulan and 
Pututan Sub-villages and Pondok Raden Patah Housing Phases 2 and 3, as marked by the blue circle (Figures $14 \mathrm{~b}-\mathrm{c})$. As for the equal scenario, it also produced the same spatial pattern as the physical and environmental scenarios (Figure 14e). It is intended as a comparison to the other four scenarios because it assumes that all parameters contribute to vulnerability at the same degree, and with this assumption, this scenario is deemed neutral [28].

Based on the above findings, the influencing factors of vulnerability are those included in the physical and environmental vulnerability scenarios. The environmental factors which are source of tidal floods and their preventive measures, as well as accessibility, while the physical determinants are the design flood elevation, building maintenance, and type of materials. These factors were embedded to house building itself. Moreover, they were very likely to experience changes in the future because most residents of Sriwulan Village made improvements at least once every five years [30]. Therefore, physical and environmental factors played important roles as "agent of change" to minimized the future risk.

Based on the previous explanation, the houses that need to be immediately modified are the ones that fall into the category of high vulnerability in the physical and environmental scenarios. There are 22 houses consistently present in this category, as shown in Table 7.

\subsection{Mitigation Measures}

Learning from previous tidal floods, the residents of Sriwulan Village have applied several mitigation efforts to the physical and environmental features that potentially contribute to vulnerability. The mitigation efforts are as follows:

\subsubsection{Design Flood Elevation}

Houses that were not affected by the tidal floods in December 2017 had been elevated by at least 2,5 meters from the original foundation (Figure 15). According to [7], to deal with tidal flood in residential areas was by raising the design flood elevation above the highest high-water level (HHWL) [9]. Regarding the value of HHWL in Demak sea water as observed during 2016 was about 2.14 meters [31].

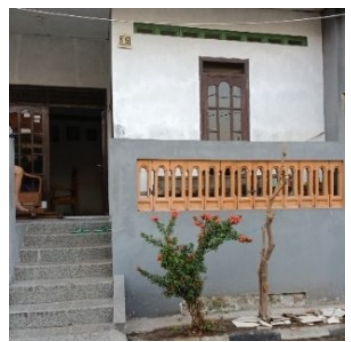

Fig. 15. House with at least 2 Meters Design Flood Elevation

\subsubsection{The Source of Tidal Floods and Their Preventive Measures}

Pumps are used to shorten the duration of seawater inundating the house. Low vulnerabilities were found in the center of Pondok Raden Patah Housing Phase 1 and Pututan Sub-village due to their privately owned pump or borrow one from the neighbourhood association, as shown in Figure 16.

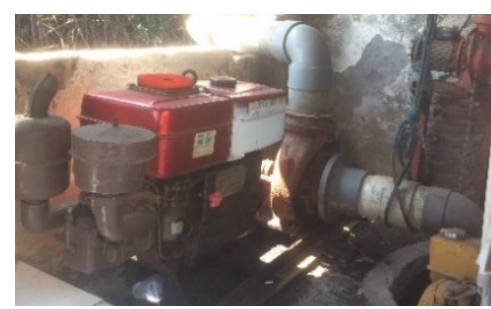

Fig. 16. House with privately owned pump

\subsubsection{Accessibility}

Bridges are installed in frequently flooded yards (Figure 17). This measure has been a great help to maintain accessibility in the event of tidal floods.

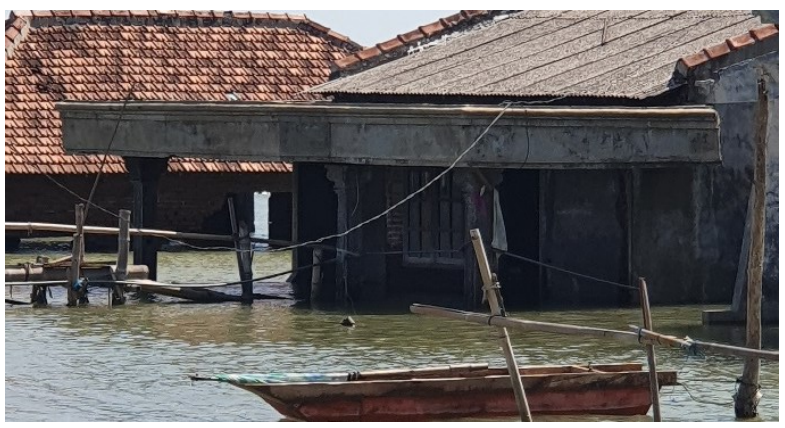

Fig. 17. House with bridge installation in the yard

\subsubsection{Building maintenance}

The residents routinely check and tend to their houses, especially the walls, which are highly vulnerable to damage. This building maintenance often includes cleaning the salt formed on brick walls, replacing wood walls at least once within five years [32], and painting cemented walls regularly, as presented in Figure 18.

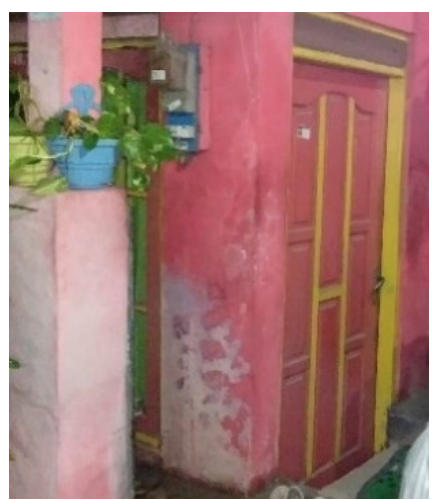

Fig. 18. House with painting cemented walls regularly 
Table 7. The Vulnerability Levels of the Sampled Houses in Physical, Environmental, and Equal Scenarios

\begin{tabular}{|c|c|c|c|}
\hline $\begin{array}{c}\text { Vulnerability } \\
\text { levels }\end{array}$ & $\begin{array}{l}\text { Number of } \\
\text { houses }\end{array}$ & $\begin{array}{l}\text { Number of houses in } \\
\text { every Sub-village }\end{array}$ & $\begin{array}{c}\text { Address } \\
\text { (Sub-village) }\end{array}$ \\
\hline \multirow[t]{6}{*}{ High } & \multirow[t]{6}{*}{22} & 13 & Nyangkringan \\
\hline & & 1 & Sriwulan \\
\hline & & 2 & Pututan \\
\hline & & 4 & Pondok Raden Patah Housing Phase 1 \\
\hline & & 2 & Pondok Raden Patah Housing Phase 2 \\
\hline & & 1 & Pondok Raden Patah Housing Phase 3 \\
\hline \multirow[t]{6}{*}{ Moderate } & \multirow[t]{6}{*}{196} & 18 & Pondok Raden Patah Housing Phase 3 \\
\hline & & 28 & Pondok Raden Patah Housing Phase 2 \\
\hline & & 66 & Pondok Raden Patah Housing Phase 1 \\
\hline & & 7 & Pututan \\
\hline & & 38 & Sriwulan \\
\hline & & 42 & Nyangkringan \\
\hline \multirow{5}{*}{ Low } & \multirow{5}{*}{45} & 2 & Pondok Raden Patah Housing Phase 3 \\
\hline & & 6 & Pondok Raden Patah Housing Phase 2 \\
\hline & & 27 & Pondok Raden Patah Housing Phase 1 \\
\hline & & 5 & Pututan \\
\hline & & 5 & Sriwulan \\
\hline
\end{tabular}

\section{Conclusion}

Referring to the results of the analysis, this research has concluded several things as follows:

1. The varying conditions of the residential buildings observed contribute to their heterogeneous degrees of vulnerability to tidal floods, i.e., low, moderate, and high. Generally, moderate vulnerability dominates the study area in all scenarios. Based on the physical and environmental scenarios, 22 houses are highly vulnerable to tidal floods, creating a robust pattern. Most of these houses are located in Nyangkringan Sub-village and a few of them are in Sriwulan and Pututan Sub-villages and Pondok Raden Patah Housing Phases 1, 2 and 3.

2. The most influencing factors of vulnerability are related to physical and environmental parameters. The physical parameters in question are the design flood elevation, building maintenance, and type of materials, while the environmental parameters include the source of tidal floods and their preventive measures, distance to water bodies, and accessibility.

This paper was one of the development of bachelor thesis from the first author. Thankyou for Universitas Gadjah Mada to support this research under the 2020 Final Assignment Recognition (RTA) as well as resident of Sriwulan Village.

\section{References}

1. Sunarto. Hakikat Bencana Kepesisiran dalam Perspektif Geomorfologi dan Upaya Pengurangan Risikonya. Jurnal Kebencanaan Indonesia. 1, 4, 211-228 (2008). In Indonesia

2. M. A. Marfai and L. King. Tidal Inundation Mapping under Enhanced Land Subsidence in Semarang, Central Java Indonesia. Nat Hazards, 44: 93-109 (2008)

3. N. M. W.A. Suryanti and M.A. Marfai. Analisis Multibahaya di Wilayah Pesisir Kabupaten Demak. Jurnal Bumi Indonesia. 5, 2 (2016). In Bahasa

4. P. Subardjo and R. Ario. Genangan Banjir Pasang pada Kawasan Permukiman di Kecamatan Sayung, Kabupaten Demak-Jawa Tengah. Jurnal Kelautan Tropis. 18, 7-12 (2015). In Bahasa

5. Suryanto. Ratusan Rumah di Desa Sriwulan Terendam Banjir Rob. Retrieved from Antara: https://www.antaranews.com/berita/226693/ratusa n-rumah-di-desa-sriwulan-terendam-rob (2010)

6. A. Widodo. Diterjang Banjir Rob, Lima Rumah Di Demak Roboh. Retrieved from Kompas: https://regional.kompas.com/read/2017/12/01/082 23971/diterjang-banjir-rob-lima-rumah-di-demakroboh (2017)

7. M. Ali. Kerugian Bangunan Perumahan Akibat Rob Dan Arah Kebijakan Penangannya. Tesis, 
Semarang: Program Master Universitas Diponegoro (2010). In Bahasa

8. A. D. Sutigno and B. Pigawati. Bentuk Adaptasi Masyarakat Terhadap Bencana Rob di Desa Sriwulan Kecamatan Sayung Kabupaten Demak. Jurnal Teknik Pembangunan Wilayah Kota 4, 4, 499-513 (2015) In Bahasa

9. D. R. Hizbaron, D. S. Hadmoko, E. T. W. Mei, S. H. Murti, M. R. T. Laksani, A. F. Tiyansyah, I. E. Tampubolon. Towards Measurable Resilience: Mapping the Vulnerability of At-Risk Community at Kelud Volcano, Indonesia. Appl. Geography, 97, 212-227 (2018)

10. A. Dewi. Community-Based Analysis of Coping with Urban Flooding: A Case Study in Semarang, Indonesia. Thesis, Netherdlands: Master ff Science in Geo-Information Science and Earth Observation. (2007).

11. FEMA. Engineering Principles and Practices for Retrofitting Flood-Prone Residential Structures. FEMA P. 259, Third Edition. (2011b).

12. FEMA. Homwowner's Guide to Retrofitting Six Way to Protect Your Home from Flooding. FEMA P-312. Second Edition. (2009).

13. R. Gentile, C. Galasso, Y. Idris, I. Rusydy, and E. Meilianda. From Rapid Visual Survey to Multi Hazard Risk Prioritisation and Numerical Fragility of School Buildings. Nat Hazards. 9, 1365-1386. (2019).

14. E. Aghimien, C. Aigbavboa, and D. Ahimien. Exploring Salt Reaction on Building Along Coastal Area in Lagos State, Nigeria- A. Rivew. Proceedings of the International Conference on Industrial Engineering and Operations Management. Pretoria/ Johannesburg, South Africa. (2018).

15. A. Tagg, K. Laverty, M. Escarameia, S. Garvin, A. Cripps, R. Craig, and A. Clutterbuck. A New Standard for Flood Resistance and Resilience of Buildings: New Build and Retrofit. In Proceeding 3rd European Conference on Flood Risk Management (2016)

16. S. J. Bates. A Critical Evaulation of Salt Weathering Impacts on Building Materials at Jazirah al Hamra, UAE. Geoverse. (2010)

17. J. Joerin, R. Shaw., \& R, R. K. Building Resilient Urban Communities. United Kingdom: Emerald Group Publishing Limited. (2014).

18. M. S. Bhuiyan. Flood Hazard and Vulnerability Assessment in A Riverine Flood Prone Area: A Case Study. Thesis. Master of Science in Water Resources Development. Banglades University of Engineering and Technology. (2014).

19. Peraturan Menteri Keuangan Republik Indonesia Nomor 7/PMK.06/2016 tentang Standar Barang dan Kebutuhan Barang Milik Negara (dengan modifikasi)

20. R. D. Kusumastuti, Viverita, Z. A. Hudoso, L. Suardi, and D. N Danarsari. Developing $A$ Resilience Index Towards Natural Disasters in Indonesia. Int. J. Disaster Risk Reduct. 10, 327-340 (2014)

21. C. Y. Ng and K. B Chuah. Evaluatin of Design Alternatives' Environmental Performance using AHP and ER Approaches. IEEE System Journal (2014)

22. G Coyle. The Analytical Hierarchy Process (AHP) Practical Strategy: Structured Tools and Technique. Glasgow: Open Access Material-Person Education Ltd. (2004)

23. D. R. Hizbaron, M. Baiquni, J. Sartohadi, R. Rijanta. Urban Vulnerability in Bantul District, Indonesia - Towards Safer and Sustainable Development. Sustainability. 4, 2022-2037 (2012)

24. M. A. Rizal, and D. R Hizbaron. Analisis Kerentanan Fisik Bahaya Banjir Lahar Di Desa Sekitar Kali Putih Kabupaten Magelang. Jurnal Bumi Indonesia Volume 4, 1, 175-184 (2015)

25. I. I Karlina And D. Mardiatno. Analisis Tingkat Kerawanan Longsor pada Sebagian Jalan Kelas IIIC di Sub-DAS Gesing, Kabupaten Purworejo. Thesis. (2016)

26. C. Rusu and V. Rusu. Radial Basis Functions Versus Geostatistic in Spatial Interpolations. Presented in IFIP International Federation for Information Processing. (2006)

27. N. M. Noor, M. M. A. B. Abdullah, A. S. Yahaya, and N.A. Ramli. Comparasion of Linear Interpolation Method and Mean Method to Replace the Missing Values in Environmental Data Set. Mater. Sci. Forum, 803, 278-281. (2014)

28. D. A. B Armaya and D. R Hizbaron. Penaksiran Tingkat Kerentanan Sosial terhadap Bahaya Banjir Lahar Pasca Erupsi Gunung Merapi (Studi Kasus: Kec. Cangkringan, Kec. Ngemplak, Kec. Kalasan Kab. Sleman). Jurnal Bumi Indonesia, 4 (2015)

29. W. Prarikeslan. Oseanografi. Jakarta: Kencana. (2016).

30. D. Harwitasari. Adaptation Responses to Tidal Flooding in Semarang, Indonesia. Thesis, Rotterdam: Master's Programme In Urban Management and Development. (2009)

31. W. S. Utami, P. Subardjo, M. Helmi. Studi Perubahan Garis Pantai Akibat Kenaikan Muka Air Laut di Kecamatan Sayung, Kabupaten Demak. Jurnal Oseanografi. 6, 1, 281-287 (2017)

32. H. Kobayashi. Vulnerability Assessment and Adaptation Strategy to Sea Level Rise in Indonesia Coastal Urban Area. Japan: National Institute for Land and Inrastructure Management. (2003) 